\title{
CORRECTION
}

\section{Diffuse skin thickening, myalgias and joint stiffness in a 41-year-old man}

CMAJ has been made aware of an error that occurred in the Mar. 5, 2018, issue. ${ }^{1}$

In the last paragraph of the section "What investigations should be ordered next?," the second sentence began "White blood cell count was $9.210^{9} / \mathrm{L}$." This should have read "White blood cell count was $9.2 \times 10^{9} /$ L."

This has been corrected at cmaj.ca.

Cite as: CMAJ 2018 April 3;190:E409. doi: 10.1503/cmaj.180321

\section{Reference}

1. Chatterjee S, Prayson RA. Diffuse skin thickening, myalgias and joint stiffness in a 41-year-old man. CMAJ 2018;190:E258-61. 